\title{
TUOMAS MÄNTYNEN
}

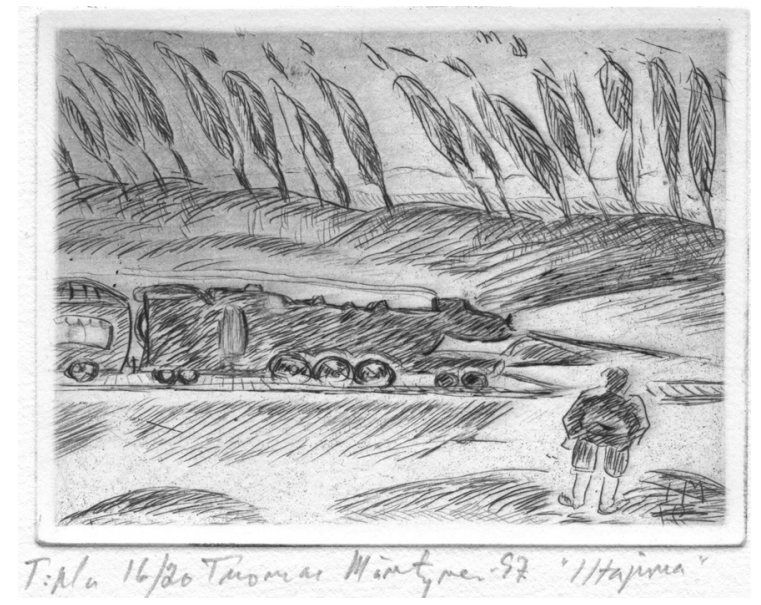

Iltajuna, 1997, viivasyövytys, 75 x 100 mm.

Taiteilija Tuomas Mäntynen (s. 1932) on kuvataiteemme lämmin ja humoristinen tarinoitsija, jonka ura alkoi jo 1950-luvulla. Maalarinopintoja hän harjoitti ensin Taideteollisessa oppilaitoksessa Onni Ojan johdolla ja sitten Vapaassa taidekoulussa Sam Vannin oppilaana. Académie de la Grande Chaumière avasi hänelle mahdollisuuden myös ulkomaisiin opintoihin modernin taiteen keskuksessa Pariisissa 1950-luvun ja 1960-luvun taitteen molemmin puolin.

Suuret eleet eivät kuulu Mäntysen tyyliin. Hän on intimisti, joka puhuttelee katsojaa taulujensa värien syvällä kerroksellisuudella ja hellyttävällä kömpelyydellä. Tummat siniset ja vihreät, joita keltainen ja punainen haastavat, ovat hänen värimaailmaansa. Mäntynen on naivisti ja valinnastaan tietoinen; hän luottaa epäakateemisen kuvailmaisun suorasukaisuuteen.

Mäntynen on myös matkamies. Hän on katuelämän tarkkailija ja kahvilassa istuja. Ihmisvilinä ja kaupunkikuvat - myös interiöörit - ovat hänen aiheitaan, mutta usein yksinäinen sivullinen todistaa tapahtumia. Hämyisissä iltahetken maisemissa hänen kolorisminsa on täyteläisintä. Maalausten tunnelma on eteläinen, vaikka aihe olisikin Pohjolan periltä.

Värit ovat Mäntysen taiteen ydintä, mutta joskus hän malttaa jättää palettinsa syrjään. Näin tapahtui 1997, kun taiteilija toipui ohitusleikkauksesta. Tässä lehdessä julkaistavia graafikko Osmo Nissisen työhuoneessa syntyneitä vedoksia Mäntynen nimittääkin "terapiasarjaksi".

Vedosten nimet vihjaavat kuoleman läheisyyteen. Pelko-viivasyövytyksessä salamaa karussa suomalaisessa maisemassa säikkynyt mies on nähnyt armottoman valomerkin. Hän pakenee kohtaloaan "ahistuneen" hulvattomasti. Vedosta voi pitää Munchin Huudon omalaatuisena serkkuna. Iltajunan veturi on salaperäinen taruotus. Minneköhän sekin puskee?

Hirtehinen eksistentialismi ja huumori ovat taiteilijan keinoja tulla juttuun väistämättömän kanssa. Hänen piirrosjälkensä on rentoa ja ilakoivaa, samalla kun itseironia ryydittää kerrontaa. Se meni-vedoksen matkalaukkuaan kannatteleva mies katsoo hämmentyneenä laiturin jättänyttä alusta. Tätäkö se elämä sitten oli? Mukava paikka on taas matkalaisen paratiisillista harmoniaa. Ei huolen häivää, kun saa ottaa yön vastaan etelän rantakahvilassa. 